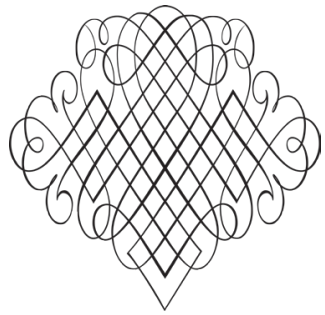

\title{
Розділ 2.
}

\section{СТАНОВАЕННЯ МУЗИЧНОГО ПРОФЕСІОНАЛІЗМУ}

УДК 782.1(450) : 7.091 .8 (477.74) «18/19»

DOI 10.34064/khnum2-1806

Бацак К. Ю.

ORCID 0000-0001-9687-093X

Київський університет імені Бориса Грінченка, бульвар Ігоря Шамо, 18/2, Київ-154, Украӥна

\section{Італійські оперні зірки харківської сцени 80-х років XIX - початку XX ст.}

АНОТАЦІЯ — Бацак К. Ю. Італійські оперні зірки харківської сцени останньої чверті XIX - початку XX ст. — Сценічні виступи відомих італійських співаків у Харкові останніх десятиліть XIX - початку XX ст. досліджуються в контексті гастрольної діяльності, яка охоплювала українські міста-культурні центри. Виявлено, що найбільшу притягальну силу у маршрутах творчих турне італійських артистів мали Київ, Одеса та Харків. Відзначені особливості репертуару італійських артистів на концертних та оперних сценах Харкова, характеристики голосів, акторська майстерність, риси вокального хисту непересічних виконавців минулого (М. Баттістіні, Дж. Беллінчоні, Е. Джіральдоні, Л. Кавальєрі, А. Мазіні, Т. Руффо та Е. Тамберліка). Описані способи комунікації італійських співаків із культурно-мистецьким середовищем Харкова у театрі та за його межами: взаємодії iз глядачем, представниками місцевих музично-педагогічних кіл. Окрема увага приділена аналізу надрукованих у регіональній пресі матеріалів про- 
фесійної музичної критики, які присвячені харківським виступам італійських майстрів. Висока оцінка критикою артистичних чеснот прославлених співаків, активна підтримка їхніх виступів публікою засвідчують непересічне значення гастрольної діяльності італійців у розвитку музичної культури Харкова - професійному становленні місцевих оперних виконавців, формуванні музичних смаків та уподобань освіченої верстви населення міста. - Ключові слова: сиенічна діяльність, італійські оперні співаки, харківська опера, культурно-мистецьке середовище, харківська музична критика.

АННОТАЦИЯ ロ Бацак К. Ю. Итальянские оперные звёзды харьковской сцены 80-х годов XIX - начала XX в. व Сценические выступления известных итальянских певцов в Харькове последних десятилетий XIX - начала XX в. исследуются в контексте гастрольной деятельности, которая охватывала украинские города-культурные центры. Выяснено, что наибольшую притягательную силу в маршрутах творческих турне итальянских артистов имели Киев, Одесса и Харьков. Отмечены особенности репертуара итальянских артистов на концертных и оперных сценах Харькова, характеристики голосов, актёрское мастерство, черты вокального таланта выдающихся исполнителей прошлого (М. Баттистини, Дж. Беллинчони, Е. Джиральдони, Л. Кавальери, А. Мазини, Т. Руффо и Е. Тамберлика). Описаны способы коммуникации итальянских певцов с культурно-художественной средой Харькова в театре и за его пределами: взаимодействия со зрителем, представителями местных музыкально-педагогических кругов. Особое внимание уделено анализу опубликованных в региональной прессе материалов профессиональной музыкальной критики, посвящённых харьковским выступлениям итальянских мастеров. Высокая оценка критикой артистических качеств прославленных певцов, активная поддержка их выступлений публикой свидетельствуют о непреходящем значении гастрольной деятельности итальянцев в развитии музыкальной культуры Харькова профессиональном становлении местных оперных исполнителей, формировании музыкальных вкусов и предпочтений образованных слоёв населения города. - Ключевые слова: сиеническая деятельность, итальянские оперные певиы, харьковская опера, культурно-художественная среда, харьковская музыкальная критика. 


\section{ABSTRACT - Batsak K. Yu. Italian opera stars at the Kharkiv stage: the 80s of the 19th - early 20th centuries.}

- Introduction. The Italian opera in Kharkiv has a long history tradition. Its beginnings date back to the $1850 \mathrm{~s}$, when the city became a part of the tour routes of Odesa Italian opera troupes under F. Berger's, V. Sermattei's direction (1850s - early 1860s), those of Taganrog - under V. Sermattei's, Corsi's and Co (second half of $1860 \mathrm{~s}-1876$ ). These little provincial troupes with unequal by quality the stuff of singers, with a little choir, usually without their own orchestra, within their possibilities, introduced the popular Italian opera repertoire to the Kharkiv audience. Technical and technological achievements - the development of the rail network, the shipping industry, the telegraph and telephone as the newest means of communication, etc., facilitated communication and, among other things, caused cultural achievements rapid exchange. Those times were marked by increasing of diffusive phenomena (in opera repertoire, in the troupe composition, etc.) in musical and theatrical arts, which, in particular, contributed to the scenic creativity activation of Italian artistes and the extension of the geography of their performances. Outstanding and average singers from the Apennines have travelled to different countries of the world with solo concert programs as part of wandering or stationary opera groups. Artistic tours to Eastern direction - to the European territories of the Russian Empire, along with touring trips to the North and South America countries, - became one of the most prevalent. Kharkiv, being one of the largest industrial and cultural centres in the Russian Empire, as a rule, was included by Italian theatre management in vocal-artistic tour programs.

Theoretical background. The problem of the famous Italian opera singers' activity on the Kharkiv stage in the 80 s of the 19 th - the beginning of the 20th is poorly investigated. Separate pages of M. Battistini's, J. Bellinchoni's, A. Mazini's, T. Ruffo's, and E. Tamberlik's biographies related to Kharkiv were studied by M. Varvartsev (2000) in his historical and biographical work "Italians in the cultural space of Ukraine (the end of 18 - 20s years of the 20th century", written in the form of a dictionary. The main source for the study of this subject were the local musicologists' (V. Sokalsky, K. Bych-Lubensky, Yu. Babetsky, etc.) theatrical reviews, published in the Kharkiv regional and city press.

Objectives. As the Italian opera art had undeniable influence on the Kharkiv musical culture development, the purpose of the article is to study the scenic activity of the famous Italian opera artistes, which acquainted the local theatrical 
audience with the assets of the world opera arts in the last decades of the 19th - early 20th century. For this purpose, the following tasks have been outlined: to find out the information potential of music-critical publications, dedicated to the Italian singers' performances, which were printed in the local press; identify and systematize the facts describing the Italian opera performers' participation in Kharkiv musical life during that period; to reveal the concert and opera repertoire, to study the evaluations of the Italian singers' performances by professional criticism, the ways of artistes' interaction with the audience; to determine the Kharkiv performances position in the famous vocalists' creative biography, to reconstruct the geography of their tour routes, included performances in Kharkiv.

The methodology involves the application of the semiotic-hermeneutic method in order to analyze the phenomena of musical-theatrical life (peculiarities of vocal-stylistic style, specificity of musical-critical thought, reactions and preferences of the audience) as a culture text and their hermeneutical understanding; bio-bibliographic method (to find out and combine facts of life and creative activity of Italian singers in Italy and abroad, in particular, in Kharkiv as well-known culture centre); cultural and historical method (allows to study the Italian singers' scenic activities as a social phenomenon, to identify social factors contributed to the spread of the Italian opera achievements in the local music and theatre environment).

Results and discussion. The study of famous Italian singers' performances on the Kharkiv stage in the definite period allowed highlighting new facts of their biographies, to analyze the concert and opera repertoire, the features of vocal and performing style, acting specifics. The research revealed the place of Kharkiv concert and opera performances in Italian artistes' touring programs, analyzed the directions and peculiarities of communicative interactions between performers and spectators, determined the Kharkiv performances place in creative biographies of vocalists who have gained European fame.

Conclusions. Italian artistes' performances had a great influence on local opera singers' professional growth, the formation of musical tastes and preferences of the educated part of the city residents. The investigation of the repertoire of the Italian singers testifies to their desire to acquaint the listener with the best achievements of European opera art, as well as to present contemporary Russian composers' operas, which, at the time, were getting popularity in the Western European countries, due, primarily, to Italian performers. Kharkiv performances 
were usually the part of Italian artistes' tours, being organized in the largest cities of Ukraine and surrounding regions of former Russian Empire - in Odesa, Kyiv, Mykolaiv, Rostov-on-Don, which testified, in particular, that the city was transformed into one of the European music culture distribution centres then. The high valuation given by the musical critique of the famous singers artistic talents, the active support of their performances by the audience, attest to the utmost importance of the Italians' touring activity in the Kharkiv musical culture development. - Key words: scenic activity, Italian opera singers, Kharkiv opera, cultural and artistic environment, Kharkiv music criticism.

Вступ. Стала традиція виступів італійської опери у Харкові бере початок від 50-х pp. XIX ст. Саме тоді італійські театральні колективи Одеси під орудою Ф. Бергера, В. Серматтеї (1850-ті пер. пол. 1860 рр.), Таганрога - антрепризи В. Серматтеї, Корсі та К ${ }^{\circ}$ (друга пол. 1860-х - 1876 р.) - обрали Харків для нетривалих гастрольних оперних сезонів. Ці провінційні колективи з нерівномірним за якістю складом співаків, невеликим хором, зазвичай без власного оркестру, знайомили, в силу можливостей, харківського глядача 3 популярним італійським оперним репертуаром. Поширення технічних і технологічних досягнень - розвиток мережі залізниць, морського пароплавства, телеграфу і телефону як новітніх засобів зв'язку - активізувало комунікацію та, крім іншого, спонукало до прискореного обміну досягненнями в царині культури.

В музично-театральному мистецтві ці часи позначилися посиленням дифузних явищ (в оперному репертуарі, виконавському складі труп тощо), які, зокрема, сприяли активізації сценічної діяльності італійських артистів та розширенню географії їхніх виступів. 3 сольними концертними програмами, у складі мандрівних чи стаціонарних оперних колективів, видатні й пересічні співаки з Апеннін подорожували різними країнами світу. Східний напрям - європейськими теренами Російської імперії - поряд із гастрольними поїздками в країни Північної та Південної Америки, став одним із найбільш поширених. Харків, який належав до числа великих індустріальних та культурних 
центрів Російської імперії, італійський театральний менеджмент зазвичай включав до програм вокально-артистичних турне.

Огляд літератури. Діяльність відомих італійських оперних співаків на харківській сцені у 80-х pp. XIX - на початку XX ст. мало вивчена. Окремі сторінки біографій М. Баттістіні, Дж. Беллінчоні, А. Мазіні, Т. Руффо, Е. Тамберліка, які пов'язані з Харковом, були досліджені М. Варварцевим в історико-біографічній праці у формі словника «Італійці в культурному просторі України (кінець XVIII 20-ті pp. ХХ ст.)» (Варварцев, 2000). Основним джерелом для вивчення означеної теми у статті слугували театральні огляди, що належать харківським музикознавцям (В. Сокальському, К. Бич-Лубенському, Ю. Бабецькому та ін.), опубліковані в харківській регіональній та міській пресі.

Мета і завдання. Оскільки італійське оперне мистецтво впродовж десятиліть здійснювало вплив на розвиток музичної культури Харкова, метою статті $є$ вивчення сценічної діяльності відомих італійських оперних артистів, які в останніх десятиліттях XIX - на початку XX ст. знайомили місцевого театрального глядача з надбаннями світового оперного мистецтва. Для цього поставлені такі завдання:

- з'ясувати інформаційний потенціал надрукованих у місцевій пресі музично-критичних публікацій, які присвячені виступам італійських співаків;

- виявити і систематизувати факти, що описують участь італійських оперних виконавців у музичному житті Харкова означеного періоду;

- характеризувати концертний та оперний репертуар, проаналізувати оцінки виступів італійських співаків професійною критикою, описати способи взаємодії артистів із глядачем;

- реконструювати географію гастрольних маршрутів відомих вокалістів та визначити місце харківських виступів у їхніх творчих біографіях.

Методологія дослідження передбачає застосування семіотико-герменевтичного методу (з метою аналізу явищ музично-театрального життя - особливостей вокально-виконавської стилістики, специфіки музично-критичної думки, реакцій та уподобань публіки - як 
тексту культури та їхнього герменевтичного осмислення); біобібліографічний метод (для з'ясування та поєднання фактів життя та творчої діяльності італійських співаків на батьківщині, в інших країнах, зокрема, в Україні); культурно-історичний метод (дозволяє дослідити сценічну діяльність італійських співаків як соціальне явище, суспільні чинники, які сприяли поширенню досягнень італійського оперного мистецтва у місцевому музично-театральному середовищі).

Виклад основного матеріалу. Енріко Тамберлік був одним із перших 3-поміж видатних італійських співаків, хто включив виступ у Харкові до концертного туру. Зірка слави цього драматичного тенора зійшла в середині ХІХ ст. У 1850 р. він успішно дебютував у лондонському Ковент Гардені в партії Мазаніелло («Німа з Портічі»), після чого артист регулярно з'являвся на сцені цього театру до 1870 р. Від 1850 до 1863 р. він виступав на сцені Санкт-Петербурзького Маріїнського театру, відзначившись дебютом у партії Альваро в «Силі долі» Дж. Верді. В цей період (1858-1877) артиста неодноразово вітали на сцені Італійської опери в Парижі. В окремі роки він гастролював за океаном - зокрема, сезон 1857 р. провів у Театро Колон Буенос-Айреса, у 1873-74 pp. співав на сцені Академії музики на Мангеттені в Нью-Йорку.

Навесні 1884 р. артист приїхав із творчим турне в Україну. 4 і 6 травня він дав концерти в Києві, виступивши в залі Купецького зібрання. Програми включали партії 3 «Ріголетто», «Трубадура» Дж. Верді тощо. В ансамблевих номерах разом із Е. Тамберліком виступили соліст Санкт-Петербурзької опери Богомир Корсов, співачки Полянська і Софія Гуревич (Богданова), учениця Поліни Віардо (Варварцев, 2000, с. 238).

12 травня 1884 р. розпочалися концерти Е. Тамберліка у Харкові, в театрі «Саду Тіволі». Разом із уславленим артистом у харківських концертах взяли участь Б. Корсов і С. Гуревич. Описуючи перший виступ Е. Тамберліка, кореспондент «Харьковских губернских ведомостей» (далі - ХГВ) показав уплив на глядачів високої майстерності й таланту артиста, який на той час уже майже не виступав. «Безголосий старець, весь пронизаний юнацькою пристрастю, - зазначав критик, - повністю підкорив своїй владі тисячний натовп, 
який переповнив концертну залу» (Искусство и литература, 1884, 13 мая). Початок виступу, здавалося, не виправдав сподівань публіки: «маленька, непоказна і товстенька фігура» артиста «з невиразним обличчям і крихітними очима» не викликала особливої симпатії. Коли пролунали перші звуки «старечого нерівного голосу, який нагадував гру надтріснутого органа», в залі навіть «учувся шепіт недружнього здивування». Але за мить глядачі вже схвильовано слухали славетного артиста. У россінієвій кантаті «Stabat mater» публіка вже не помічала неприємної вібрації голосу соліста, зачаровано слухаючи його захопливий спів (там само).

13 травня артист відвідав приватну школу співу Силуянової-Кондиревої, де прослухав у виконанні її учениць арії з «Вільгельма Телля» Россіні і «Гальки» С. Монюшка. За кілька днів співака запросили до Харківського музичного училища IPMO (засноване 1883 р.), де він слухав виступи К. Коляновської, Кнепфер і Давидової - учениць колишньої оперної співачки К. Прохорової-Мауреллі. Викладачці й директору училища I. Слатіну Е. Тамберлік висловив «повне задоволення з приводу почутого і побаченого ним», а трьом ученицям, які співали, передбачив видатне артистичне майбуття (Искусство и литература, 1884, 17 мая). Зокрема, К. Коляновська за його порадою відбула до Парижа, де впродовж 1884-86 рр. брала уроки співу у П. Віардо, ставши пізніше оперною й камерною співачкою (колоратурне сопрано), відомою на Заході та в Україні (Варварцев, 2000, с. 238).

3 Харкова Е. Тамберлік вирушив до Одеси, де дав два концерти у залі біржі та на сцені Російського театру (21 і 26 травня). В першому 3 них артист відзначився виконанням канцонети 3 «Ріголетто» (Концерт Тамберлика..., 1884, 23 мая) та в дуеті 3 россінієвого «Отелло», де йому підкорилося «славнозвісне ut diese» (Б., 1884, 17 мая). Під час виступу в залі Російського театру гість разом із компаньйонами - скрипалем Саленом, солістами С. Гуревич, Б. Корсовим і співачкою Стефані, виконали тріо з «Вільгельма Телля» Дж. Россіні, романс із «Марти» Ф. фон Флотова, тріо із «Ломбардців» та квартет із «Ріголетто» Дж. Верді (Второй концерт..., 1884, 25 мая).

В останній декаді травня Е. Тамберліка запросили виступити в двох концертах у театрі Монте в Миколаєві (Э. Тамберлик в Ни- 
колаеве, 1884, 26 мая). У цих концертах артист особливо відзначився у тріо 3 «Вільгельма Телля», в якому він «уразив слухачів гучністю, силою й оксамитовим звучанням високих нот та чудовою майстерністю виконання» (Вчерашний второй концерт..., 1884, 27 мая).

3 Харковом були пов'язані гастрольні маршрути тенора $\boldsymbol{A}$. Мазіні, якого в цей час іменували «королем тенорів». На професійній сцені співак з'явився 1867 р. в Модені. Потім виступав у театрах Мантуї, Болоньї, Венеції, Палермо, Флоренції, Парижа, Лондона, Відня. Упродовж 1877-1904 рр. співав переважно за кордоном: у Петербурзі, Москві, Мадриді, Барселоні та Лісабоні (Варварцев, 2000, с. 152).

У квітні 1895 р. А. Мазіні з тріумфом здійснив артистичну поїздку містами України. Після трьох концертів у Одеській опері, останній $з$ яких прозвучав 7 квітня, він 11 квітня виступив у переповненій залі київського Купецького зібрання (там само), а 16 і 18 квітня його вітали в Харківському оперному театрі (зала Комерційного клубу). Разом із А. Мазіні у цьому концертному турне брали участь співаки Джудічі (сопрано), Карусон (баритон), Де-Пробіцці (бас) та піаніст-акомпаніатор Гаммієрі. Програми включали арії, дуети, тріо з опер «Шукачі перлин» Ж. Бізе, «Фаворитка» Г. Доніцетті, «Трубадур», «Ріголетто», «Луїза Міллер» Дж. Верді, «Сільська честь» П. Масканьї, «Мефістофель» А. Бойто, «Дон Жуан» В. А. Моцарта, «Фауст» Ш. Гуно, «Гугеноти» Дж. Мейєрбера, а також романси та пісні. Для заохочення публіки, яка вперше зустрічалася з іменитим артистом, у місцевій пресі вихваляли його сценічні успіхи в Москві й Петербурзі, згадували про недавні незабутні концерти в Одесі, де вже під час першого виступу «театр був заповнений вщерть згори донизу», а задоволення виступом артиста вимірювалося п'ятнадцятиразовими викликами на bis (Театр и музыка, 1895, 8 апр.).

Після першого харківського концерту А. Мазіні газети стверджували, що він так само сподобався місцевій публіці, «як і в тих містах, у яких йому доводилося виступати з концертами». Про це, зокрема, свідчила кількість номерів соло, виконаних на bis - замість чотирьох, що були заявлені у програмі, він проспівав дванадцять (Театр и музыка, 1895, 17 апр.). На вимогу глядачів були повторені усі дуети за участю А. Мазіні. Після виконання артистом арії Фердинанда 
(«Spirito gentil») iз «Фаворитки» Г. Доніцетті артисту піднесли лавровий вінок зі стрічками італійських національних кольорів (Театр и музыка, 1895, 17(29) апр.).

Під час другого концерту успіх А. Мазіні «йшов crescendo». Кілька виконаних ним неаполітанських народних пісень викликали найвище захоплення публіки, яка влаштувала овації (Театр и музыка, 1895, 18(30) апр.). Особливо активною серед глядачів була молодь. «Після деяких номерів, проспіваних Мазіні, які особливо сподобалися, - писали "ХГВ”, - в театрі наростав повсюдний шум, після якого вже потім слідували нескінченні вигуки bis. А після завершення концерту публіка однозначно не бажала розходитися, виклики змінювали один одного. Артист дякував за висловлені захоплення i, йдучи на поступку, заспівав на прощання, вже без акомпанементу, ще один романс. Цей прощальний романс був покритий громом оплесків» (Театр и музыка, 1895, 20 апр.).

Причини такого успіху артиста місцева критика вбачала в унікальності його артистичного таланту. «Надзвичайна м'якість, легкість і гнучкість голосу, - зазначав музичний кореспондент часопису “Южный край”, - утворюють феноменальне явище; до цього всього слід додати цілковито своєрідну, сповнену художнього смаку і блиску, манеру передачі творів, яка іноді порушує справжність тексту, але, попри це, завжди зачаровує. Невимушеність і свобода у співі при надзвичайно розвинутому диханні вражають кожного; але Мазіні майже не послуговується своєю останньою перевагою, і зрідка, лише там, де це доречно, робить фермати» (Театр и музыка, 1895, 18(30) апр.). Глядачів уразила майстерність, з якою артист відтворював динамічні відтінки - його чудове pianissimo, рівне, без жодної вібрації, було свідченням високого «мистецтва управління людським голосом» (там само). Про успіх свідчили також суми грошових зборів - два концерти дали 5200 рублів касових надходжень (там само). Ця творча поїздка мала продовження в Ростові-на-Дону, куди А. Мазіні вирушив одразу після харківських бенефісів.

Наступного року до Харкова 3 концертами прибув молодий обдарований баритон Еудженіо Джсіральдоні. Його найбільші успіхи - дебют у першій постановці «Тоски» Дж. Пуччіні (Барон Скарпіа) у Театрі 
Костанца в Римі (1900), виконання італійської версії «Євгенія Онєгіна» в Ла Скала (1900), гучні виступи в Метрополітен Опера Нью-Йорка були ще попереду. Тому особливо цікавим є висновок харківської критики про артистичний талант дебютанта, який, щоправда, до приїзду в Харків уже відзначився на сцені імператорської опери Петербурга. У програмі концерту, в якому Е. Джіральдоні виступив разом із відомим лірико-колоратурним сопрано Є. Мравіною, були виконані дуети із «Гамлета» А. Тома та «Ріголетто» Дж. Верді, сольно артист проспівав арії з «Шукачів перлин», куплети Тореадора 3 «Кармен» Ш. Бізе, «Іродіади» Ж. Массне та епіталаму із «Нерона» А. Рубінштейна (Сегодня в оперном театре..., 1896, 24 февр.). Даючи оцінку цьому виступу, харківський музичний кореспондент далекоглядно відзначав: «Пан Джіральдоні - добрий співак. Широкий за діапазоном, молодий і соковитий голос, музичність, уміле долання виконавських труднощів обіцяють йому блискуче майбуття» (Театр и музыка, 1896, 26 февр.).

У грудні 1895 р. в Харкові вперше виступила Джемма Беллінчоні. У другій половині 1880-х - на початку 1890 років вона стала відомою в Італії завдяки гучному успіхові у вердіївській «Травіаті» (Ла Скала, Мілан, 1886), а також після пам'ятного дебюту в партії Сантуцци на прем’єрі «Сільської честі» П. Масканьї (разом із майбутнім чоловіком Р. Станьйо) в римському Театро Костанца.

У програмі харківських гастролей співачки були передбачені два виступи в постановках місцевої оперної трупи - в партії Віолетти в «Травіаті» (13 грудня) та в ролі Кармен в однойменній опері Ж. Бізе (15 грудня). Виступ італійки в «Травіаті» став незабутнім, перетворивши цю виставу на «видатний спектакль сезону». Всі номери у виконанні примадонни, навіть ті, котрі, як писала преса, «в інших виконавиць проходять непоміченими», здобули гучні оплески. Характеризуючи вияв артистичного таланту співачки в партії Віолетти, кореспондент «ХГВ» писав: «Великий, широкий за регістром гарного тембру голос артистки, його чудова рухливість, уміння артистки самим лише звуком голосу відзначити найтонші відтінки душевного стану ролі, яка передається i, нарешті, iï глибоко продумана гра, - все це створює гарне, цільне враження і приносить величезну естетичну насолоду слухачам» (Театр и музыка, 1895, 13 дек.). 
Зовсім інше, навіть протилежне, враження склалося від виконання Дж. Беллінчоні партії Кармен. Хоча і в цій виставі артистка демонструвала «чудову школу, відмінне piano і чітке фразування», вибір партії в теситурі мецо-сопрано змусив виконавицю співати у деяких місцях на терцію чи навіть на октаву вище, звук іiі голосу в середніх нотах звучав тьмяно і здавався «занадто відкритим». Кармен в інтерпретації Дж. Беллінчоні виявилась занадто «вульгарною», від чого була майже зовсім втрачена «принадність, яка... повинна бути у севільської звабниці» (Театр и музыка, 1895, 15 дек.). До того ж, на думку критики, артистка грала занадто жваво, надмірно, до судом, гримасуючи. Абсурдність прийомів гіпертрофованої гри неприємно дивувала у сцені сварки Кармен із Хозе у третьому акті вистави (там само).

Після Харкова Дж. Беллінчоні мала виступити в Києві, на запрошення дирекції міського театру (Варварцев, 2000, с. 37), та в Одесі, де був навіть анонсований дебют артистки у партії Кармен. Проте виступи не відбулися з причини хвороби примадонни (Тоника, 1896, 3 янв.). Дебютні гастролі Дж. Беллінчоні в Одесі були організовані 1899 р., після чого вона вдруге відвідала Харків. Упродовж січня 1900 р. знаменита артистка виступила у виставах місцевої оперної трупи: у вердіївській «Травіаті», «Фаусті» Ш. Гуно, «Сільській честі» П. Масканьї, «Паяцах» Р. Леонкавалло, «Севільському цирульнику» Дж. Россіні і «Міньйон» А. Тома. У відгуку про виконання партії Маргарити у «Фаусті» зазначалося, що вона була проспівана 3 «не меншим блиском», ніж Травіата. Підкреслювали високохудожнє і реалістичне виконання артисткою дуету третього акту, іiї «неперевершений» спів у «Арії з перлами», де «кожна фразочка і кожна нотка були ніби справжні перлини», а також відтворені нею $з$ приголомшливим драматизмом сцена в храмі й сцена смерті Валентина. У співі артистки особливо вражала надзвичайна легкість переходів від одного регістру до іншого (К. Б., 1900, 9 янв.).

Виступи Дж. Беллінчоні в «Паяцах» і «Сільській честі» видалися найкращими у іiї гастрольній програмі. Відзначали особливий дар перевтілення артистки: в «Паяцах» було дві різні Коломбіни - при в їзді в натовпі та на ярмарковій сцені, і потім, після антракту, ста- 
лася ще одна кардинальна зміна образу - тепер на підмостках побачили «просту грубувату, але сповнену кохання дівчину з Півдня», в якій «не було жодної риси, яка нагадувала б вам Коломбіну, або саму артистку» (К. Б., 1900, 11 янв.). «Слухаючи і споглядаючи саму пані Беллінчоні, - схвильовано відзначав критик, - направду, навіть прикро, що мимоволі говориш про високе драматичне мистецтво могутньої артистки, а не про іiі спів, музичне виконання. Але всі їі ресурси так тісно зрощені один із одним, що ніяк не дозволяє розділити їх, розкласти на складники» (там само).

Дж. Беллінчоні вдалося розважити харківських глядачів виконанням партії Розіни в «Севільському цирульнику» Дж. Россіні. Відмовившись від «солодкаво-шаблонних» романсів у сцені уроку, артистка приємно здивувала завсідників театру виконанням іспанських романсів, чим додала опері «рідного їй» колориту (К. Б., 1900, 15 янв.). У виконанні партії Міньйон артистка найбільше запам'яталася в останньому терцеті, в якому «проста мелодія», виконана з виразністю, довершила зворушливий образ ії героїні (там само).

На початку березня 1902 р. Дж. Беллінчоні знову відвідала Харків, виступивши, як і першого разу, разом із місцевою оперною трупою. Напередодні іiі приїзду харківська критика шанобливо згадувала про минулі харківські бенефіси примадонни, відзначивши позитивний вплив взірцевого стилю та школи співачки на професійне зростання молодих співаків, які тоді переважали в оперній трупі міського театру (Бич-Лубенский, 1902, 3 дек.). Програма виступів Дж. Беллінчоні майже повністю відтворювала репертуар 1900 року: 3 грудня вона розпочала 3 «Травіати», потім співала в «Кармен», а іï прощальний вечір у харківській опері ознаменувався виставами «Паяців» та «Сільської честі». Анонсуючи гастролі знаменитої італійки, газета «Южный край» зазначала, що «чудовий голос, виразність передачі, симпатична зовнішність, відмінна міміка, тонка обробка сценічних прийомів», усе те, що в більшості інших артистів зустрічається окремо, у Дж. Беллінчоні поєднане в єдине ціле, а «живий темперамент, який зігріває і наснажує виконання артистки, дозволяє їй однаково добре передавати найрізноманітніші почуття і порухи людської душі» (Театр и музыка, 1902, 3 дек.). 
Попри ідентичність програм 1900 та 1902 років, Дж. Беллінчоні змогла запропонувати харківському глядачеві нові інтерпретації образів, чим здивувала і заохотила до похвал місцеву критику. «Три роки тому, - пише К. Бич-Лубенський про виступ артистки у “Травіаті”, пані Беллінчоні зобразила цю героїню в першій дії молоденькою дівчиною, яка щойно відпила 3 отруйної чаші куртизанства, і в такому напрямі провела всю першу дію. У звітному спектаклі діва створила образ молодої жриці напівсвіту, яка знає ціну всім зізнанням. <..> I знову новий штрих, нова картина: не простодушна юна істота боязно прислухається до нового почуття, а людина, яка довго на нього чекала і визріла для нього» (там само). Артистка натхненно виконала фінальну арію першого акту («Ah, fors’è lui che l'anima»): навіть без слів у «вогненних звуках мелодії, у чудовому й відкритому обличчі незрівнянної артистки» глядач міг відчути глибокі переживання героїні. У співі діви відзначили «легку і прозору» трель, «досконалі й чудові гами», що свідчило про його технічну довершеність (там само). Драматизм, який наповнює третій i, особливо, четвертий акти «Травіати», Дж. Беллінчоні передала з глибоким реалізмом: «тут артистка не звертається до жодного зовнішнього прийому, щоб посилити або підкреслити враження, навпаки, вона навіть немов уникає ïx, i лише сила музичної експресії і глибоко правдива інтерпретація магічно приковують до неї слухача і захоплюють його, вражаючи до глибини душі», - підкреслює К. Бич-Лубенський (там само).

Цього разу в «Кармен» Дж. Беллінчоні була зовсім іншою, ніж у свій перший приїзд: глядачів потішили чуття міри і художнє наповнення сценічної дії - ніякої афектації, награної театральності, зайвої міміки та жестів. Чудове враження залишив виступ співачки в третьому акті. Глибока втома й байдужість проступали у ставленні до розлюбленого Хозе завдяки «спокійній і дещо грубуватій» манері гри артистки, передчуття катастрофи вчувалося і в оригінальній сцені ворожіння на картах, яку вона провела без «ходульних театральних жахань». Майстерність Дж. Беллінчоні-Кармен сягнула вершин вишуканості й артистизму у фіналі цієї дії. Після бурхливої суперечки з Хозе, коли Кармен іде з Мікаелою, відбувається «чудова мімічна сцена». Після насилля колишнього коханця ніби розриваються усі 
взаємини, які іï з ним поєднували: «вона неначе про щось згадує, два помахи рукою, і пальці самі по собі клацають, імітуючи звук кастаньєт, пригадується перша поява Ескамільйо-Тореадора, який щойно пішов. Його пісня лунає вдалині. Артистка на мить замислилась, а потім, попрощавшись із контрабандистами, спокійно й рішуче йде “туди, де на неї чекає кохання”», - так описував цю сцену самовидець (Бич-Лубенский, 1902, 9 дек.).

Характеризуючи особливість артистичної натури Дж. Беллінчоні, у якій «гармонійно поєдналось у єдине ціле все, що потрібно оперній співачці», порівнюючи враження від іiї останніх харківських гастролей 3 попереднім приїздом, В. Сокальський відзначав: «Усе та ж сама в неї симпатична зовнішність, струнка, по-юнацьки гнучка молода фігура, тонке, нервове, рухливе обличчя, осяяне чудовими очима, той самий надзвичайний по широті діапазону і легкості вокалізації голос, глибокий грудний голос, у якому зовнішня принадність звукового забарвлення так чудово зливається з щирістю й задушевністю виразності; та сама розмаїта міміка, ті самі рухи, сповнені природної жвавості й невимушеної грації; та сама гра, яка то захоплює своєю кипучою пристрастю, то наповнюється найніжнішою, пестливою, чарівливою жіночністю; те саме вміння одягатися красиво і доречно» (Дон-Диэз, 1902, 7 дек.).

За кілька років харків'яни почули голос нової зірки італійського оперного мистецтва - баритона Timma Pyффо. Артист уперше приїздив до України в грудні 1904 - січні 1905 р., коли був ангажований антрепренеркою одеського міського театру М. Лубковською на ряд вистав у сезоні італійської опери, потім він вирушив до Петербурга, де співав у Театрі Консерваторії. Через рік, узимку 1906 р., Т. Руффо знову приїздив до Петербурга на запрошення князя-антрепренера Олексія Церетелі для виступів у антрепризі його «Нової опери». Саме О. Церетелі, за словами співака, після завершення петербурзького контракту організував його артистичне турне, в ході якого Т. Руффо разом із іншими європейськими знаменитостями співав на сценах ряду великих міст Російської імперії, серед яких були українські Харків та Київ (Ruffo, Т., 1977, с. 221).

Особливістю весняного оперного сезону в Харкові, розпочатого 3 квітня, була конкуренція одразу двох оперних труп - 
Р. Карамзіної-Жуковської в залі Комерційного клубу (Харківській опері) та «Товариства Є. Кабанова і В. Валентінова» у Малому театрі. У кожний $з$ колективів були запрошені італійці: в антрепризі Р. Карамзіної-Жуковської співав тенор Вінченцо Коппола, а в Малому театрі анонсували виступи Т. Руффо, примадонни-сопрано Марії Гальвані разом із польською співачкою Яніною Вайдою-Королевич, які обидві вже здобули європейську славу, а також тенора Гаспарі. Невдовзі після відкриття антреприза в Харківській опері збанкрутіла і всі запрошені співаки об'єднались для виступів у трупі Малого театру.

Дебютний виступ Т. Руффо відбувся 3 квітня в «Ріголетто» (Джільда - М. Гальвані, Герцог - Гаспарі). Анонсуючи оперні вистави за участю видатного співака, газета «Южный край» повідомляла читачів про його успіхи в театрі Ла Скала, славетні виступи в Петербурзі, коли він «затьмарив самого Баттістіні» (Дон-Диэз, 1906, 5 апр.). В. Сокальський, задоволений першим виступом італійця, дав високу оцінку його таланту: «Пан Тітта Руффо дійсно виявився справжнім артистом, відмінним в усіх відношеннях, - писав критик, - Чи багато взагалі оперних артистів, наділених не лише гарним голосом, музичним і сценічним талантом, а також наполегливістю і працелюбністю, необхідними для ретельної обробки цих цінних дарів природи? Пан Т. Руффо - один із небагатьох таких артистів...» (там само). Далі, описуючи переваги вокального таланту співака, критик відзначив: «У п. Тітта-Руффо голос рідкісний за силою і красою тембру, дивовижний за гнучкістю і розмаїттям звукового забарвлення. I як він ним володіє! Щонайменшого натяку на дешевий крик. Це справжній, благородний спів, те саме bel canto, таємницю якого осягнули, здається, одні лише італійці, але й ті не всі... Якщо додати до цього видатний сценічний талант, завдяки якому на сцені весь час рухається не шаблонний оперний манекен, а живе обличчя, яке невмисно захопило глядача усіма своїми радощами й стражданнями, нарешті, щирість і захоплення, якими пронизане все виконання артиста, то стане зрозумілою та чарівлива привабливість, під яку підпадає публіка, слухаючи пана Тітта Руффо» (там само). 
Вистава «Демона» А. Рубінштейна, в якій узяв участь Т. Руффо, стала ще одним тріумфом італійця. Артист готував партію Демона вдома і з великим успіхом іiі вперше презентував під час одеських бенефісів 1904-1905 рр. У Харкові в образі Тамари блискуче виступила Я. Вайда-Королевич, місцеві співаки добре виконали другорядні партії Сінодала, Янгола, чисто прозвучав хор. Т. Руффо вдалося підкреслити «людську» природу лермонтовського Демона, позбувшись в образі свого героя «фантастичності, грізної величі» (Дон-Диэз, 1906, 7 апр.). «I як чудово співав цей симпатичний Демон у стражданні, - наголошує критик, - якими ніжними мереживами оксамитових звуків обплітав він довірливе серце Тамари на перших із нею зустрічах; яким почуттям, пристрастю, вогнем дихали його слова наприкінці, перед самою фатальною розв'язкою» (там само).

Змальовуючи переваги звучання голосу артиста в образі Демона, кореспондент «ХГВ» відзначав: «Звичайно, з виконанням артиста багато в чому можна не погоджуватися; але його чарівний, гнучкий, м'який, у верхньому регістрі тенорового відтінку голос, викуповував усе. Диханням він володіє чудово, теzza voce і piano має прекрасні, хоча ними й мало послуговується. Він ніби сам захоплюється силою та красою свого голосу і дає такі звуки, хвилям яких, здається, немає меж» (Театр и музыка, 1906, 11 апр.). Величезний успіх видатного Т. Руффо виявився у безкінечних викликах на bis, вибухах овацій. Арію «Не плачь, дитя» йому довелося проспівати тричі, вдруге він, на догоду глядачам, виконав іiі російською мовою, чим збурив хвилю захоплення (там само). Чудовою партнеркою італійцю була Я. Вайда-Королевич, яка наповнила партію Тамари «почуттям і вишуканістю» (там само).

У «Травіаті», поставленій 7 квітня, відзнаки, крім Т. Руффо Жермона, дісталися М. Гальвані у партії Травіати та В. Копполі в образі Альфреда (Дон-Диэз, 1906, 9 апр.). Вистава «Трубадура», яка завершила короткий весняний оперний сезон у Малому театрі, принесла нові артистичні лаври Т. Руффо (Граф Луна) та іншим головним виконавцям - Я. Вайді-Королевич (Елеонора) і В. Копполі (Манріко). Публіка захоплено вітала італійських артистів, влаштовуючи їм бурхливі прощальні овації (Дон-Диэз, 1906, 12 апр.). За під- 
сумками сезону виявилось, що майже всі опери за участю Т. Руффо збирали повну залу, а це є безсумнівним свідченням фінансового успіху антрепренерів.

3 Харкова розпочалося майже річне турне видатного баритона містами України. Спочатку Т. Руффо вирушив до Києва, де 11-22 квітня виступав у театрі Соловцова, потім співав у міському театрі Одеси (27-30 квітня). Наступного місяця артист повернувся до Києва, щоб разом із М. Гальвані взяти участь у концерті, організованому в приміщенні цирку. А з 19 жовтня він знову співав на київській сцені - цього разу його ангажували для виступів у вісімнадцяти репертуарних виставах міського театру (Варварцев, 2000, с. 212).

Невдовзі після від'їзду Т. Руффо до Харкова прибула популярна зірка італійської опери Ліна Кавальєрі. Співачка зупинилася в місті дорогою до Одеси з Києва (Театр и музыка, 1906, 1 мая), де виступила в шести виставах оперного сезону міського театру (17-28 квітня) (Варварцев, 2000, с. 126). Упродовж трьох днів артистка виступила у «Манон» (28 квітня) та «Травіаті» (29 і 30 квітня) разом із ліричним тенором Арістодемо Джорджіні, солістом Петербурзької імператорської опери. Розпочавши сценічну кар'єру як кафешантанна співачка, Л. Кавальєрі 1900 р. перейшла на оперну сцену і дебютувала в «Паяцах» Р. Леонкавалло в театрі Лісабона. Згодом співала в Монте-Карло (1904р.), в Театрі Сари Бернар у Парижі, де разом iз Е. Карузо взяла участь у постановці опери «Федора» У. Джордано. Перед гастрольною поїздкою містами України діва виступала в Маріїнському театрі північної столиці імперії, запам'ятавшись в опері «Таїс» Ж. Массне. Хоча Л. Кавальєрі багато працювала з вокальними педагогами, щоб розвинути свій від природи невеликий голос, сценічну славу вона здобула переважно завдяки привабливій зовнішності та щирості виконання ліричних партій. Її вважали еталоном краси, фотозображення діви поширювалися величезними накладами в усій Європі. Кореспондент «ХГВ», сповіщаючи про приїзд Л. Кавальєрі, відзначав, що про неї знають у місті переважно завдяки «численним і різноманітним листівкам, які можна знайти в кожному домі», тому харків'яни в більшості прийшли до театру, щоб «роздивитися артистку поближче» (Marcato, 1906, 30 апр.). 
Партія Манон у виконанні гастролерки не задовольнила музичних критиків - хоча артистка детально опрацювала вокальний матеріал, звучання iï голосу було нерівним: гучний у високих нотах, він лунав тьмяно при переході в середній регістр. «Простій» грі, яка супроводжувалася дещо штучною жестикуляцією, бракувало невимушеності та природності (там само). Значно кращим було враження від виступу примадонни у «Травіаті». Голос співачки на високих нотах звучав так само добре, але в середніх вчувалася хрипота, а колоратура в першому акті «бажала кращого». Проте «вся партія була так добре опрацьована й оздоблена, що всі недоліки повністю згладжувались» (Marcato, 1906, 2 мая). Гра артистки в ході вистави поступово вирівнялася і в третьому акті «вона виступила задушевно, без афектації та дешевих ефектів» (там само).

Тенор А. Джорджіні співав дуже добре, глядачам настільки сподобався його м'який, красивий голос, що в партії Де Гріє артиста попросили повторити кілька номерів на bis (Marcato, 1906, 30 апр.). У другій дії «Травіати» А. Джорджіні-Альфред буквально «зачарував» публіку виконанням своєї арії - так багато «легкості, вишуканості й принадності було в його співі», а такого чудового piano, на думку критика, давно не чули на харківській сцені (Marcato, 1906, 2 мая). Враження від виступу не зіпсувала навіть неритмічність співу в деяких місцях партії.

Під час виступів Л. Кавальєрі не обійшлося без інцидентів. Оскільки вхідні квитки на вистави популярної співачки коштували дуже дорого, зала була напівпорожньою, в той час як біля театру зібрався натовп, який попри все прагнув потрапити всередину і його не могли втримати ні зачинені двері, ні поліція. До кінця вистави «Манон» зала переповнилась, овації, спочатку скромні, в останні моменти набули «бурхливо-стихійного характеру» (Дон-Диэз, 1906, 30 апр.). «Враження було зовсім зіпсоване, з одного боку, задухою, яка стала наслідком того, що всі проходи були загачені якоюсь публікою, котра, очевидно, не мала визначених місць, а з іншого боку, тією дикістю, з якою та сама публіка кинулась після третьої дії подивитися на розкішний костюм і діаманти, вбрані співачкою», - бідкався газетний кореспондент. Перед сценою виникла тиснява, публіка перших 
рядів змішалася з прийшлою, яка в прагненні досягнути сцени топтала крісла й бруднила вбрання багатих дам (Marcato, 1906, 30 апр.). На довершення всього, за браком квітів, артистів на сцені почали закидати кашкетами та ридикюлями - цей спосіб вияву захоплення видався дивним навіть бувалим театралам (Дон-Диэз, 1906, 30 апр.). Під час наступного виступу Л. Кавальєрі заворушення в театрі набули загрозливих масштабів. Ось як описує очевидець перебіг подій під час вистави «Травіати» 29 квітня: «Попри неймовірні зусилля поліції 37 до 12 години стримувати зовні цю публіку, вона примудрялася і ворота виламувати, i по одному прориватися, i, врешті решт, в останній дії цілим натовпом увірвалася до театру. На цей раз не лише нещасні глядачі перших рядів, але й весь партер втратив можливість що-небудь бачити чи чути через гамір і той натовп, який стіною увірвався (в капелюхах і пальтах) та зручно розташувався перед першим рядом і в усіх проходах. <..> У дворі при вході продовжувалось звалище, якийсь юнак налаштовував публіку проти поліції, очевидно, через те, що вона не пропускає в театр...» (Marcato, 1906, 2 мая).

Відомий італійський співак Mammia Батmістіні вперше виступив у Харкові 1902 р. під час гастрольної поїздки містами України, коли він подорожував у складі оперної трупи антрепренера Ф. Кастеллано (Варварцев, 2000, с. 33). Окрім Харкова, упродовж року це артистичне співтовариство виступило у багатьох значних містах України: Одесі, Києві, Катеринославі та Слисаветграді. До Харкова «король баритонів» приїхав після гучних бенефісів у київському театрі Соловцова, де трупа Ф. Кастеллано гастролювала наприкінці березня - на початку квітня 1902 р.

Свої гастролі М. Баттістіні розпочав виступом у партії Герцога де Шеврез доніцеттієвої «Марії ді Роган». Хоча анонс цієї «старої» опери не викликав особливого інтересу публіки - близько третини місць у театрі були порожніми, - дебют видатного співака став незабутнім. За кілька днів музичний кореспондент захоплено ділився враженнями на сторінках «ХГВ». «3 першої появи його на сцені, з першого ж звуку його голосу відчувається, що перед слухачем - справжній артист, - писав К. Бич-Лубенський. - Ось він співає свою вихідну величезну арію. I не знаємо, чому більше дивуватися: чи голосу 
артиста, чи його вражаючому мистецтву. Могутній, широкий голос розливається всією театральною залою, виблискуючи нескінченними переливами, цілим спектром звуків: то глибоким низьким тоном віолончельного тембру, то mezza voce часто тенорового тембру, то металевою середньою нотою. Звуки ці то розростаються до найсильнішого forte, то стихають до найніжнішого piano. I помітно: співакові усі ці численні модуляції ніби нічого не варті: найвищі ноти баритонового регістру (до la включно) дістаються йому так само легко, як, наприклад, середнє do; найсильніше форте не містить в собі й натяку на напруження; співак завжди співає, а не кричить... Вражає також майстерність п. Баттістіні передавати звуками почуття, яке хвилює в цю хвилину зображуваного героя: меланхолійний смуток, глибоке горе, вибух гніву, - все це артист зображує своїм співом зрозуміло для всякого, хто не лише не розуміє по-італійськи, а й навіть не знає лібрето опери» (Бич-Лубенский, 1902, 19 апр.).

Незабутнє враження від співу й гри М. Баттістіні та його партнерів викликало резонанс серед містян, і вже під час наступного виступу видатного баритона в «Ернані» Дж. Верді зала була заповнена вщерть. Артист співав партію Карла V. Він приємно дивував цільністю створеного образу. «Костюми його характерні, відповідають епосі, - відзначав В. Сокальський, - а струнка, гнучка фігура артиста завжди вигідно для себе виділяється у будь-якому вбранні. Рухливе обличчя і його жваві очі, як світле дзеркало, легко й швидко відображають у собі всі відтінки різноманітних душевних станів. Хода, жести його завжди шляхетні, красиві й не виходять за межі художньої міри» (Дон-Диэз, 1902, 18 апр.). Відзначали, що навіть у найспокійніші моменти в його грі, в його міміці й жестах відчувалася дивовижна сила пристрасті й одухотвореності, яка мимоволі передавалася глядачеві (там само). Публіка постійно переривала виконання бурхливими вигуками захоплення, які артист гідно сприймав, кланявся «із видом короля, поблажливого до слабостей своїх підданих». Лише одного разу М. Баттістіні не стерпів безцеремонного поводження з його мистецтвом. В «Марії ді Роган», коли він співав партію Де Шевреза, в момент найбільшого емоційного напруження з-за лаштунків несподівано вискочив служник із букетом квітів, ніби бажаючи втішити героя 
в його горі. Поява «розрадника» викликала на обличчі артиста бурю емоцій - мить, і служник з букетом зник зі сцени (там само).

На думку критики, М. Баттістіні в поставленому 17 квітня «Гамлеті» А. Тома створив «диво», повернувши на сцену в «ріденькій» i «шаблонній» опері з «понівеченим лібрето» замість «томасівського Гамлета» шекспірівського Принца Данського. «Яку б ми не взяли сцену, яку б не привели арію, речитатив чи драматичний епізод, - характеризує К. Бич-Лубенський цей виступ, - усе так наповнене безкінечними епізодами найрізноманітніших душевних настроїв, які так майстерно передаються, що геть забуваєш про Баттістіні...» (Бич-Лубенский, 1902, 20 апр.).

Вистава моцартового «Дон Жуана» не мала великого успіху, перш за все, через те, що італійські артисти в більшості не змогли передати простоту й витонченість стилю композитора ні співом, ні грою. Критик відзначав, що публіка в театрі відверто нудьгувала, більшість цікавих номерів пройшли непоміченими - відомий дует «Дай ручку мені, Церліно» та «неперевершене за концепцією голосів» тріо Дон Жуана, Командора і Лепорелло в сцені після дуелі (Бич-Лубенский, 1902, 24 апр.). Багато артистів трупи не зрозуміли своїх ролей: Лепорелло-Веккіоні, який мав добрий голос, був недостатньо рухливим і комічним, Петруччі із Мазетто зробив «повного дурня», Феррайолі-Командор занадто багато жестикулював, що «не дуже личило мармуровій статуї», непомітними в своїх партіях були примадонна Нунец-Ельвіра та співак Мотекуккі-Октавіо. Непогано виступила в партії Церліни артистка Таманті, яка мала «невеликий, але досить приємний голос» (Дон-Диэз, 1902, 23 апр.). М. Баттістіні в цій опері показав «різнобічність та гнучкість» свого таланту: партія Дон Жуана дозволила у всій повноті виявити властиву йому артистичну витонченість. Виконанням серенади він настільки полонив публіку, що змушений був повторити іiі тричі, і кожного разу співав iї з новими відтінками голосу й фразування, давши наочний приклад того, як багато різноманітних ефектів може створити в одному на позір простому номері великий митець (там само).

Бурхливі овації, безліч квітів, коштовні подарунки (два срібні сервізи) отримав артист за виконання партії Ріголетто в опері, яка 
завершувала його коротку гастрольну програму. Чудово прозвучали обидва дуети 3 Джільдою (співачка Аск'єрі), відома арія третього акту «Pietate, signori», i, особливо, «Vendetta» (Бич-Лубенский, 1902, 25 апр.). Відмінною рисою сценічного таланту М. Баттістіні була дивовижна цілісність, єдність кожного створеного ним образу при ретельній розробці найдрібніших деталей. Усяку зображувану особу він умів показати з різних сторін, відтінивши їх влучними штрихами. «Кожний порух душі у нього одразу знаходить собі зовнішній вираз у позі, жесті, міміці обличчя, тембрі й інтонації голосу», - відзначав В. Сокальський (Дон-Диэз, 1902, 27 апр.). Саме тому створений артистом образ Ріголетто не нагадував шаблонних «старих придворних блазнів» з їхньою «самолюбивою дратівливістю, похмурою підозріливістю і злісною мстивістю». М. Баттістіні у свого героя показує «картину людської душі з усіма переплетеннями усіляких суперечливих почуттів, які в ній, вочевидь, так легко співіснують поряд» (там само). Артисту вдалося особливо відтінити трагічний бік особистості блазня: його Ріголетто - це нещасна людина, обділена природою і людьми, з глибокою пристрасною душею, в якій «любов і ненависть киплять однаково сильно і нестримно» (там само).

Найбільше зацікавлення глядачів викликав виступ М. Баттістіні в «Свгенії Онєгіні», якого трупа поставила 19 квітня за італійським лібрето. I Баттістіні-Онєгіну, і Адаберто-Тетяні вдалося не втратити авторського задуму в образах героїв, додавши, щоправда, дещицю італійського колориту. Онєгін у передачі Баттістіні виявився більш жвавим, струнка сповнена енергії фігура італійського артиста і його рухливе обличчя надавали Онєгіну більше сили і пристрасності, ніж у російських виконавців, i, разом з тим, його Онєгін був «показним і блискучим», «справжнім джентльменом», кожен жест якого, кожне слово виражали «шляхетність і витонченість натури» (Дон-Диэз, 1902, 21 апр.). Дуже стримано, без зайвого пафосу провів артист першу сцену з Тетяною в саду: він ніби співчуває дівчині, підбадьорює і втішає, «не в змозі відповісти на їі кохання», але останню сцену італієць проводить з неймовірно «полум' яною юнацькою пристрастю» (там само). Єдине, чого, як вважає критик, не вдалося відтворити М. Баттістіні, це задуманого композитором «мелодійного речитативу», який додає 
довершеності звучання діалогам героїв. «Баттістіні багато розмов Онєгіна розуміє, вочевидь, як «сухий речитатив» (recitative secco), констатує В. Сокальський, - і тому в його виконанні применшується їхня чисто музична краса...» (там само). Опера була вдалою - майже кожному виконавцю дісталися оплески. М. Баттістіні «увесь час був предметом бурхливих овацій», заключний монолог передостанньої картини він мусив повторити чотири рази (там само).

Вдруге М. Баттістіні приїхав до Харкова після тривалої перерви, напередодні Першої Світової війни. Він прибув до столиці Слобожанщини після здобутого тріумфу у Петербурзі й Москві (Гастроли Маттиа Баттистини, 1914, 6 февр.). У першій половині лютого 1914 р. артист виступив в приміщенні «Нової опери» у п’яти виставах - «Ріголетто», «Балі-маскараді», «Ернані», «Севільському цирульнику» та «Демоні». Частина партій у його виконанні вже була відома харківському глядачеві, інші були представлені вперше. Харківські виступи артиста відбулися з величезним успіхом: у «Ріголетто» він змушений був повторити фінал, а після п'ятнадцяти викликів наприкінці опери шанувальники подарували улюбленому співакові «величезний» кошик квітів (Эмбе, 1914, 9 февр.). В «Балі-маскараді» зала «тряслася» від захоплення публіки його виконанням «арії біля дзеркала» («Eri tu»), яку артист потім проспівав на bis, знову були квіти (Эмбе, 1914, 12 февр.), в «Ернані» співак в черговий раз був на вершині слави - він повторив на вимогу публіки звернення до Ельвіри і каватину Карла V (Эмбе, 1914, 16 февр.).

Але особливий інтерес викликала участь маестро у виставі «Демона» 12 лютого. М. Баттістіні був першим з італійських співаків, які вивчили італійську версію рубінштейнівського «Демона». Уже після нього до цього образу звертались Е. Джілардоні, Л. Піньялоза i T. Руффо. Створюючи образ Демона, М. Баттістіні позбавляє його тонких жіночних рис грішного янгола «зі спрагою невдоволеної пристрасті», а постає «титаном, якого скинули на землю, могутнім, нездоланним, який осягнув уперше, після зустрічі з Тамарою, «тугу кохання, його сум'яття» (Эмбе, 1914, 14 февр.). Дивовижно правдиве виконання артиста заворожувало глядачів, захоплювало критику. «Передача знаменитого романсу "Не плачь, дитя" - це істинний ше- 
девр, і можна сказати, що так його ще ніхто не виконував, і навряд чи хто коли-небудь так виконає! - схвильовано писав музичний кореспондент. - А арія “На воздушном океане”! Це якийсь криштально-прозорий, невагомо чистий і зефіроподібний спів!» (там само). Вражала самовидця й інтонаційна чіткість виконання, і ясність та рівність звуку («як звук доброго Страдіваріуса»), і відсутність будь-якої хворобливої вібрації, захоплювало багатство обертонів (там само). Виснажлива сцена в келії, яку артист провів на величезному підйомі, неодноразово переривалась оплесками, а наприкінці вистави пролунали безкінечні овації. «А співав так, що слухачі не бажали йти 3 театру» - резюмував критик (там само).

Це був останній приїзд М. Баттістіні до Харкова. Початок Першої світової війни, у якій Італія опинилася у ворожому до Російської імперії воєнно-політичному блоці, розгортання воєнних дій на західному прикордонні, зупинив виступи майже всіх італійських артистів на підросійських теренах України.

Висновки. Дослідження виступів відомих італійських співаків на сценічних майданчиках Харкова в останніх десятиліттях XIX - на початку XX ст. дозволило виявити маловідомі факти їхніх біографій, 3'ясувати концертний та оперний репертуар, визначити риси вокально-виконавського стилю, особливості акторської гри. Висока оцінка критикою артистичних чеснот прославлених співаків, активна підтримка їхніх виступів публікою засвідчують непересічне значення гастрольної діяльності італійців у розвитку музичної культури Харкова. Великий вплив ця діяльність мала на професійне становлення місцевих оперних виконавців, формування музичних смаків та уподобань освіченої верстви населення міста. Вивчення репертуару, представленого італійськими співаками, засвідчує їхнє прагнення ознайомити слухача 3 кращими здобутками європейського оперного мистецтва, представити оперні твори сучасних російських композиторів, які, завдяки передусім італійським виконавцям, у той час набували популярності в країнах Західної Європи. Харківські виступи зазвичай входили до гастрольних турів італійських артистів, які організовувались у найбільших містах України та прилеглих регіонів тогочасної Російської імперії - Одесі, Києві, Миколаєві, Ростові-на-Дону, що 
свідчило, зокрема, про перетворення міста на один із центрів поширення європейської музичної культури.

\section{ЛІТЕРАТУРА}

Б. (1884). Тамберлик в Одессе (письмо в редакцию). Одесский вестник, 113, 17 мая.

Бич-Лубенский, К. (1902). Во втором спектакле г-жа Беллинчони... Харьковские губернские ведомости, 320, 9 дек.

Бич-Лубенский, К. (1902). Театр и музыка. Харьковские губернские ведомости, 99, 19 апр.

Бич-Лубенский, К. (1902). Театр и музыка. Харьковские губернские ведомости, 100, 20 апр.

Бич-Лубенский, К. (1902). Театр и музыка. Харьковские губернские ведомости, 103, 24 апр.

Бич-Лубенский, К. (1902). Театр и музыка. Харьковские губернские ведомости, 105, 25 апр.

Бич-Лубенский, К. (1902). Театр и музыка. Харьковские губернские ведомости, 315, 3 дек.

Бич-Лубенский, К. (1902). Гастроли Беллинчони. Харьковские губернские ведомости, 317, 5 дек.

Варварцев, М. (2000). Італійці в культурному просторі України (кінець XVIII - 20-ті рр. ХХ ст.): історико-біографічне дослідження. (Словник). Київ: [б. в.], 324.

Второй концерт г-на Тамберлика. (1884). Одесский вестник, 115, 25 мая.

Вчерашний второй концерт Тамберлика. (1884). Одесский вестник, 117, 27 мая.

Гастроли Маттиа Баттистини. (1914). Южный край, 11879, 6 февр.

Дон-Диэз [Сокальський, В.]. (1902). Музыкальные заметки. Южный край, 7351, 21 апр.

Дон-Диэз [Сокальський, В.]. (1902). Музыкальные заметки. Южный край, 7353, 23 апр.

Дон-Диэз [Сокальський, В.]. (1902). Музыкальные заметки. Южный край, 7357, 27 апр.

Дон-Диэз [Сокальський, В.]. (1902). Музыкальные заметки. Южный край, 7576, 7 дек. 
Дон-Диэз [Сокальський, В.]. (1906). Музыкальные заметки. Южный край, 8749, 5 апр.

Дон-Диэз [Сокальський, В.]. (1906). Музыкальные заметки. Южный край, 8751, 7 апр.

Дон-Диэз [Сокальський, В.]. (1906). Музыкальные заметки. Южный край, 8753, 9 апр.

Дон-Диэз [Сокальський, В.]. (1906). Музыкальные заметки. Южный край, 8756, 12 апр.

Дон-Диэз [Сокальський, В.]. (1906). Оперный театр. Южный край, 8774, 30 апр.

Дон-Диэз [Сокальський, В.]. (1902). Театр и музыка. Южный край, 7348, 18 апр.

Искусство и литература. (1884). Харьковские губернские ведомости, 120, 13 мая.

Искусство и литература. (1884). Харьковские губернские ведомости, 123, 17 мая.

К. Б. (1900). Театр и музыка. Харьковские губернские ведомости, 7, 9 янв.

К. Б. (1900). Театр и музыка. Харьковские губернские ведомости, 9, 11 янв.

К. Б. (1900). Театр и музыка. Харьковские губернские ведомости, 13, 15 янв. Концерт Тамберлика... (1884). Одесский вестник, 113, 23 мая.

Marcato. (1906). Оперный театр. Харьковские губернские ведомости, 95, 30 апр.

Marcato. (1906). Оперный театр. Харьковские губернские ведомости, 96, 2 мая.

Сегодня в оперном театре состоится... (1896). Харьковские губернские ведомости, 50, 24 февр..

Театр и музыка. (1895). Харьковские губернски еведомости, 89, 8 апр.

Театр и музыка. (1895). Харьковские губернские ведомости, 98, 17 апр.

Театр и музыка. (1895). Харьковские губернские ведомости, 101, 20 апр.

Театр и музыка. (1895). Харьковские губернские ведомости, 323, 13 дек.

Театр и музыка. (1895). Харьковские губернские ведомости, 325, 15 дек.

Театр и музыка. (1896). Харьковские губернские ведомости, 52, 26 февр.

Театр и музыка. (1895). Южный край, 4901, 17 (29) апр.

Театр и музыка. (1895). Южный край, 4902, 18 (30) апр.

Театр и музыка. (1902). Южный край, 7572, 3 дек. 
Театр и музыка. (1906). Южный край, 8775, 1 мая.

Театр и музыка. Малый театр. (1906). Харьковские губернские ведомости, 79, 11 апр.

Тоника. (1896). Городской театр. Театр, 3, 3 янв.

Э. Тамберлик в Николаеве. (1884). Одесский вестник, 116, 26 мая.

Эмбе, Е. [Бабецький, Ю.]. (1914). Первая гастроль М. Баттистини. Южный край, 11885, 9 февр.

Эмбе, Е. [Бабецький, Ю.]. (1914). Вторая гастроль М. Баттистини. Южный край, 11890, 12 февр.

Эмбе, Е. М. [Бабецький, Ю.]. (1914). Баттистини в «Демоне». Южный край, 11894, 14 февр.

Эмбе, Е. М. [Бабецький, Ю.]. (1914). Баттистини в «Эрнани». Южный край, 11897, 16 февр.

Ruffo, T. (1977). La mia parabola: Memorie. Milano: Staderini editore, 444.

\section{REFERENCES}

B. (1884). Tamberlik v Odesse (pismo v redakciyu) [Tamberlik in Odesa (a letter in the editorial office)]. Odesskiy vestnik - Odesa Herald, 113, May 17 [in Russian].

Bich-Lubenskiy, K. (1902). Gastroli Bellinchoni [Bellinchioni’s concert tour]. Kharkovskiye gubernskiye vedomosti - Kharkiv Provincial Gazette, 317, December 5 [in Russian].

Bich-Lubenskiy, K. (1902). Teatr i muzyka [Theatre and music]. Kharkovskiye gubernskiye vedomosti - Kharkiv Provincial Gazette, 99, April 19 [in Russian].

Bich-Lubenskiy, K. (1902). Teatr i muzyka [Theatre and music]. Kharkovskiye gubernskiye vedomosti - Kharkiv Provincial Gazette, 100, April 20 [in Russian].

Bich-Lubenskiy, K. (1902). Teatr i muzyka [Theatre and music]. Kharkovskiye gubernskiye vedomosti - Kharkiv Provincial Gazette, 103, April 24 [in Russian].

Bich-Lubenskiy, K. (1902). Teatr i muzyka [Theatre and music]. Kharkovskiye gubernskiye vedomosti - Kharkiv Provincial Gazette, 105, April 25 [in Russian]. 
Bich-Lubenskiy, K. (1902). Teatr i muzyka [Theatre and music]. Kharkovskiye gubernskiye vedomosti - Kharkiv Provincial Gazette, 315, December 3 [in Russian].

Bich-Lubenskiy, K. (1902). Vo vtorom spektakle g-zha Bellinchoni... [In the second performance mrs. Bellinchioni...]. Kharkovskiye gubernskiye vedomosti - Kharkiv Provincial Gazette, 320, December 9 [in Russian].

Don-Diez [Sokalskij, V.]. (1902). Muzykalnye zametki [Musical Notes]. Yuzhnyy kray - Yuzhnyy kray - South Region, 7351, April 21 [in Russian].

Don-Diez [Sokalskiy, V.]. (1902). Muzykalnye zametki [Musical Notes]. Yuzhnyy kray - South Region, 7353, April 23 [in Russian].

Don-Diez [Sokalskiy, V.]. (1902). Muzykalnye zametki [Musical Notes]. Yuzhnyy kray - South Region, 7357, April 27 [in Russian].

Don-Diez [Sokalskiy, V.]. (1902). Muzykalnye zametki [Musical Notes]. Yuzhnyy kray - South Region, 7576, December 7 [in Russian].

Don-Diez [Sokalskiy, V.]. (1902). Teatr i muzyka [Theatre and Music]. Yuzhnyy kray - South Region, 7348, April 18 [in Russian].

Don-Diez [Sokalskiy, V.]. (1906). Muzykalnye zametki [Musical Notes]. Yuzhnyy kray - South Region, 8751, April 7 [in Russian].

Don-Diez [Sokalskiy, V.]. (1906). Muzykalnye zametki [Musical Notes]. Yuzhnyy kray - South Region, 8753, April 9 [in Russian].

Don-Diez [Sokalskiy, V.]. (1906). Muzykalnye zametki [Musical Notes]. Yuzhnyy kray - South Region, 8756, April 12 [in Russian].

Don-Diez [Sokalskiy, V.]. (1906). Muzykanye zametki [Musical Notes]. Yuzhnyy kray - South Region, 8749, April 5 [in Russian].

Don-Diez [Sokalskiy, V.]. (1906). Opernyy teatr [Opera theatre]. Yuzhnyy kraySouth Region, 8774, April 30 [in Russian].

E. Tamberlik v Nikolaeve [E. Tamberlik in Nikolayev]. (1884). Odesskiy vestnikOdesa Herald, 116, May 26 [in Russian].

Embe, E. [Babetskiy, Yu.]. (1914). Battistini v «Demone» [Battistini in "Demon”]. Yuzhnyy kray - South Region, 11894, February 14 [in Russian].

Embe, E. [Babetskiy, Yu.]. (1914). Battistini v «Ernani» [Battistini in "Ernani”]. Yuzhnyy kray - South Region, 11897, February 16 [in Russian].

Embe, E. [Babetskiy, Yu.]. (1914). Pervaya gastrol M. Battistini [The first M. Battistini's performance tour]. Yuzhnyy kray - South Region, 11885, February 9 [in Russian]. 
Embe, E. [Babetskiy, Yu.]. (1914). Vtoraya gastrol M. Battistini [The second M. Battistini's performance tour]. Yuzhnyy kray - South Region, 11890. February 12 [in Russian].

Gastroli Mattia Battistini [Mattia Battistini's tour]. (1914). Yuzhnyy kray - South Region, 11879, February 6 [in Russian].

Iskusstvo i literatura [Arts and Literature]. (1884). Kharkovskiye gubernskiye vedomosti - Kharkiv Provincial Gazette, 120, May 13 [in Russian].

Iskusstvo i literatura [Arts and Literature]. (1884). Kharkovskiye gubernskiye vedomosti-Kharkiv Provincial Gazette, 123, May 17 [in Russian].

K. B. (1900). Teatr i muzyka [Theatre and Music]. Kharkovskiye gubernskiye vedomosti - Kharkiv Provincial Gazette, 7, January 9 [in Russian].

K. B. (1900). Teatr i muzyka [Theatre and Music]. Kharkovskiye gubernskiye vedomosti - Kharkiv Provincial Gazette, 9, January 11 [in Russian].

K. B. (1900). Teatr i muzyka [Theatre and Music]. Kharkovskiye gubernskiye vedomosti - Kharkiv Provincial Gazette, 13, January 15 [in Russian].

Koncert Tamberlika... [Tamberlik's concert...]. (1884). Odesskiy vestnik-Odesa Herald, 113, May 23 [in Russian].

Marcato. (1906). Opernyy teatr [Opera Theatre]. Kharkovskiye gubernskiye vedomosti - Kharkiv Provincial Gazette, 95, April 30 [in Russian].

Marcato. (1906). Opernyy teatr [Opera Theatre]. Kharkovskiye gubernskiye vedomosti - Kharkiv Provincial Gazette, 96, May 2 [in Russian].

Ruffo, T. (1990). La mia parabola: Memorie [My parabola: Memories]. Milan: Staderini editor, 444 [in Italian].

Segodnja v opernom teatre sostoitsja... [Today at the opera house will be held ...]. (1896). Kharkovskiye gubernskiye vedomosti - Kharkiv Provincial Gazette, 50, February 24 [in Russian].

Teatr i muzyka [Theatre and Music]. (1895). Kharkovskiye gubernskiye vedomosti - Kharkiv Provincial Gazette, 89, April 8 [in Russian].

Teatr i muzyka [Theatre and Music]. (1895). Kharkovskiye gubernskiye vedomosti - Kharkiv Provincial Gazette, 98, April 17 [in Russian].

Teatr i muzyka [Theatre and Music]. (1895). Kharkovskiye gubernskiye vedomosti - Kharkiv Provincial Gazette, 101, April 20 [in Russian].

Teatr i muzyka [Theatre and Music]. (1895). Kharkovskiye gubernskiye vedomosti - Kharkiv Provincial Gazette, 323, December 13 [in Russian]. 
Teatr i muzyka [Theatre and Music]. (1895). Kharkovskiye gubernskiye vedomosti - Kharkiv Provincial Gazette, 325, December 15 [in Russian].

Teatr i muzyka [Theatre and Music]. (1895). Yuzhnyy kray - South Region, 4901, April 17 (29) [in Russian].

Teatr i muzyka [Theatre and Music]. (1895). Yuzhnyy kray - South Region, 4902, April 18 (30) [in Russian].

Teatr i muzyka [Theatre and Music]. (1896). Kharkovskiye gubernskiye vedomosti - Kharkiv Provincial Gazette, 52, February 26 [in Russian].

Teatr i muzyka [Theatre and Music]. (1902). Yuzhnyy kray - South Region, 7572, December 3 [in Russian].

Teatr i muzyka [Theatre and Music]. (1906). Yuzhnyy kray - South Region, 8775, May 1 [in Russian].

Teatr i muzyka. Malyy teatr [Theatre and Music. Maly Theatre]. (1906). Kharkovskiye gubernskiye vedomosti - Kharkiv Provincial Gazette, 79, April 11 [in Russian].

Tonika. (1896). Gorodskoy teatr [City Theatre]. Theatre, 3, January 3 [in Russian]. Varvartsev, M. M. (2000). Italiitsi v kulturnomu prostori Ukrainy (kinets XVIII 20-ti rr. XX st. [Italians in the cultural space of Ukraine (the end of 18th20 s years of 20 century]: historic-biographical research. (Dictionary). Kyiv: [n. ed.], 324 [in Ukrainian].

Vcherashniy vtoroy contsert Tamberlika [Tamberlik's yesterday second concert]. (1884). Odesskiy vestnik - Odesa Herald, 117, May 27 [in Russian].

Vtoroy kontsert g-na Tamberlika [Mr. Tamberlik's second concert]. (1884). Odesskiy vestnik - Odesa Herald, 115, May 25 [in Russian]. 